\title{
Komparasi Teori Marketing Politik 4p Menurut Niffenegger dan 3p Menurut Adman Nursal
}

\section{Comparison of $4 p$ Political Marketing Theory According to Niffenegger and $3 p$ According to Adman Nursal}

\author{
Sutrisno*, Neneng Yani Yuningsih, Leo Agustino \\ Departemen Ilmu Politik, Fakultas Ilmu Sosial dan Ilmu Politik \\ Universitas Padjadjaran, Indonesia
}

Diterima: Juni 2018; Disetujui: Desember 2018; Dipublish: Desember 2018

\begin{abstract}
Abstrak
Penelitian ini bertujuan untuk mendeskripsikan, serta menganalisis Komparasi Teori Marketing Politik $4 \mathrm{p}$ Menurut Niffenegger dan 3p Menurut Adman Nursal. Yang pertama yaitu marketing politik yang menggunakan teori strategi pendekatan pasar (Nursal 2004) yang dikenal dengan istilah 3P yaitu Pull Marketing, Push marketing, dan Pass marketing. Kemudian yang kedua yaitu marketing politik yang menggunakan teori bauran marketing atau marketing-mix (Niffenneger 1989) atau 4P yaitu product, promotion, price dan place. Artikel ini akan membahas mengenai perbedaan dan persamaan dari kedua teori tersebut. Marketing politik di dalam Pemilihan Kepala Daerah telah banyak digunakan sebagai strategi pemenangannya. Banyak dari strategi tersebut memiliki ke khasan tersendiri agar dapat diterima dengan baik oleh masyarakat. Konsep marketing yang diadaptasi dalam dunia politik, dapat digunakan untuk meningkatkan efisiensi dan efektifitas transfer ideologi dan program kerja, dari kontestan ke masyarakat dalam sebuah kampanye. Pada penelitian ini peneliti menggunakan metode studi literatur. Studi literatur adalah serangkaian kegiatan yang berkenaan dengan metode pengumpulan data pustaka, membaca dan mencatat, serta mengelolah bahan penelitian. Hasil penelitian menunjukan kedua teori dapat saling melengkapi di lapangan. Teori Niffenneger untuk memahami peta pemasaran politik. Sedangkan teori adman nursal lebih kepada teknik promosi kandidat di akar rumput.

Kata kunci : Markating Politik, Kampanye, Pemilihan Umum
\end{abstract}

\begin{abstract}
This study describe, as well as analyze Comparative Political Marketing Theory $4 p$ According Niffenegger and $3 p$ According to Adman Nursal. The first is the marketing of politics that uses the theory of market approach strategy (Nursal 2004) called 3P terms are Pull Marketing, Push marketing, and Pass marketing. Then the second is marketing politics using marketing mix or marketing mix (Niffenneger 1989), known as 4P, product, promotion, price and place. This article will discuss the differences and similarities of both theories. Political marketing has been used as a winning strategy. Many of these strategies have their own to be well received by the public. Marketing concepts adapted in politics used to improve the efficiency and effectiveness of ideological transfers and work programs, from contestants to the public in a campaign. In this study researchers used literature study method. The literature study used library data collection methods, reading and recording, as well as managing research materials. The results of the study show that both theories can complement each other in the field. Niffenneger's theory for understanding political marketing maps. While Adman Nursery's theory is more about candidate promotion techniques at the grassroots.
\end{abstract}

Keywords: Political Markating, Campaign, General Election

How to Cite: Sutrisno, Neneng, Y.Y. \& Leo, A. (2018). Komparasi Teori Marketing Politik 4p Menurut Niffenegger dan 3p Menurut Adman Nursal. JPPUMA: Jurnal Ilmu Pemerintahan dan Sosial Politik UMA (Journal of Governance and Political Social UMA), 6 (2): 106-111

\footnotetext{
${ }^{*}$ Corresponding author:

E-mail: trisno.log@gmail.com
} ISSN 2549-1660 (Print) ISSN 2550-1305 (Online) 


\section{PENDAHULUAN}

Perubahan mendasar dalam politik dunia bertepatan dengan runtuhnya sistem ideologis komunis. Keruntuhan Tembok Berlin menandai perubahan ini. Tembok Berlin merupakan manifestasi dari pemisahan dua ideologi di era Perang Dingin. Akibatnya, demokrasi lahir di bidang ekonomi dan politik kapitalisme. Demokratisasi, termasuk prinsip kesetaraan hak asasi manusia dan hak politik, telah memperlemah sistem kantong-kantong otoriter.

Di sisi lain, gelombang demokratisasi merupakan tren global sepanjang hayat. Banyak negara berkembang yang dipimpin oleh system demokrasi tidak terkecuali Indonesia. Salah satu keunggulan demokrasi adalah penyelenggaraan pemilihan umum, termasuk pemilihan pejabat publik atau kepala daerah setempat. Dalam kondisi ini memberi peluang kepada masing-masing pihak untuk memenangkan pemilihan. Salah satu produk reformasi adalah pemilihan langsung kepala negara. Pemilihan kepala negara dianggap sebagai tindakan demokratis karena orang dapat berpartisipasi dalam menentukan sikap mereka terhadap pemerintah dan daerah. Pemilihan pemimpin daerah merupakan perwujudan demokrasi di mana rakyat memasuki struktur pemerintahan melalui pemilihan.

Ilmu marketing sangat baik dan cocok digunakan dalam berkampanye dalam rangka mendapatkan simpati dari pemilih. Karena itu, marketing politik merupakan strategi pemenangan yang mencakup berbagai aspek. Marketing politik yang baik tentunya harus memiliki tujuan yang terukur, sehingga sosialisasi bisa diterima dengan baik oleh masyarakat.

Alih-alih hanya sekedar menjual partai atau kandidat belaka, marketing politik disisi lain juga menawarkan konsep tentang bagaimana partai politik atau kandidat menciptakan konsep prosedural dengan permasalahan yang nyata.
O'Class (1996) berpendapat bahwa tujuan dari kegiatan analisis, perencanaan, pelaksanaan dari sebuah marketing politik dalam pemilu adalah untuk menciptakan hubungan yang baik serta saling menguntungkan antara pasangan calon dan pemilih untuk mencapai kesuksesan.

Ketika kita berbicara tentang marketing sering identik dengan penjualan atau dunia bisnis, hal ini tidak selalu terjadi. Marketing sebenarnya bisa digunakan di bidang politik dan bidang lainnya. Dalam hal ini marketing politik dapat dilakukan dengan berbagai cara. Misalnya dalam hari besar keagamaan banyak ucapan dari para politisi di setiap sudut jalan, mulai dari ucapan selamat bulan ramadhan, selamat natal, selamat hari raya idul fitri dan lain sebagainya. Dengan menunjukkan visi, misi, ideologi, tujuan dan program partai untuk memperbaiki citra kandidat, banyak dilakukan melalui marketing politik.

Setelah era reformasi dimana adanya pemilihan presiden ataupun pemilihan kepala daerah yang dipilih secara langsung, banyak penelitian atau riset yang mengangkat tema tentang marketing politik. Dari sekian banyak penelitian mengenai marketing politik maka dapat dikategorikan menjadi dua pendekatan besar.

Pertama, yaitu marketing politik yang menggunakan teori strategi pendekatan pasar (Nursal, 2004) yang disebut dengan istilah 3P yaitu Push marketing, Pull Marketing, dan Pass marketing.

Pendekatan push marketing yaitu adanya stimulan atau rangsangan yang diberikan oleh pasangan calon kepada pemilih sehingga mendorong mereka pergi ke Tempat Pemungutan Suara (TPS ) dan mencoblos. Kemudian pull marketing yaitu pembentukan image pasangan calon sehingga memiliki dampak terhadap pemilih yang diharapkan mampu membangkitkan sentimen pemilih. Dan yang ketiga yaitu pass marketing yaitu 
strategi yang menggunakan individu atau kelompok untuk mempengaruhi opini pemilih.

Kedua, yaitu marketing politik yang menggunakan teori gabungan marketing atau marketing-mix (Niffenneger, 1989) yang dikenal dengan istilah 4P yaitu product, promotion, price dan place. Yang pertama adalah product, product dari sebuah partai politik salah satunya adalah pasangan calon yang memiliki ciri pribadi dan track record yang baik. Kedua yaitu promotion, bagaimana seorang calon melakukan promosi atau iklan mengenai visi, misi, dan program selama kampanye. Ketiga yaitu price atau harga, yang dimaksud harga di sini adalah seberapa besar biaya yang dikeluarkan selama masa kampanye. Kemudian yang keempat yaitu place atau tempat, tim kampanye pasangan calon harus dapat melakukan pemetaan terhadap struktur maupun karakteristik dari suatu masyarakat.

\section{METODE PENELITIAN}

Pada penelitian ini peneliti menggunakan metode studi literatur atau kepustakaan. Studi literatur adalah serangkaian kegiatan yang berkenaan dengan metode pengumpulan data pustaka, membaca dan mencatat, serta mengelolah bahan penelitian. Menurut Danial dan Warsiah (2009), studi literatur merupakan penelitian yang dilakukan oleh peneliti dengan mengumpulkan sejumlah buku atau majalah yang berkaitan dengan masalah dan tujuan penelitian. Teknik ini dilakukan dengan tujuan untuk mengungkapkan beragam teori yang relevan dengan permasalahan yang sedang diteliti sebagai bahan rujukan dalam pembahasan hasil penelitian yang akan diteliti.

Penggunaan teknik studi literatur dilakukan menggunakan metode heuristik, yaitu mengumpulkan sumber dan data yang diperlukan yang memiiki keterkaitan dengan tema penelitian yang diangkat. Langkah selanjutnya dilakukan dengan membaca secara seksama literatur yang ada baik berupa buku, catatan, artikel dan majalah, atau makalah yang berhubungan dengan penelitian, kemudian peneliti akan menghubungkan data-data literatur yang berhubungan dengan masalah penelitian, mencatat serta mengolah bahan penelitian.

Rujukan utama peneliti adalah Literatur yang ditulis Niffenegger dalam jurnal of consumer marketing Vol. 30 Tahun 1989 dan buku karya Adman Nursal yang diterbitkan tahun 2004 berjudul Political Marketing Strategi Memenangkan Pemilu Sebuah Pendekatan Baru Kampanye Pemilihan DPR, DPD, Presiden, Terbitan Gramedia.

\section{HASIL DAN PEMBAHASAN \\ Marketing Politik 4p Menurut Niffenegger}

Proses marketing politik memiliki kesamaan dengan proses marketing komersial namun tidak serupa, ketidak serupaan tersebut terdapat pada hal-hal yang dibahas pada setiap tahap proses antara marketing komersial dan marketing politik. Proses marketing politik menurut Niffenneger (1989) memiliki bauran marketing 4P. Dalam ekonomi, bauran marketing 4P adalah sesuatu yang sudah dikenal banyak orang. Tetapi 4P dalam marketing politik memiliki nuansa yang berbeda dari yang diterapkan dalam dunia bisnis pada kehidupan sehari-hari (Firmanzah, 2012). Berikut adalah 4P dalam proses marketing politik:

1. Product

Niffengger membagi produk politik menjadi tiga kategori, platform partai, masa lalu kandidat, dan karakteristik pribadi kandidat. Produk utama dari partai politik tentunya adalah platform atau paradigma partai yang mengandung konsep, identitas ideologis dan program kerja dari partai politik itu sendiri. Dalam hal ini perlu dilihat bagaimana platform partai pendukung, track record pasangan calon dan karakteristiknya. 


\section{Promotion}

Dalam marketing politik harus menggunakan promosi sebagai alat untuk "menjual" produk politik yaitu pasangan calon. Promosi yang baik bukanlah keberuntungan, promosi yang baik harus menempatkan dengan tepat di mana penjualan akan berlangsung, bagaimana jalannya promosi dan untuk siapa promosi itu dilakukan. Dalam hal ini, bagaimana kampanye pasangan calon menentukan apakah promosinya berhasil atau tidak? Dalam promosi pasangan calon harus berpikir, Jargon apa yang baik, bahwa media berhak untuk bekerja sama dengannya, dan siapakah artis yang diundang, artis seperti apakah yang dapat mempengaruhi suara.

\section{Price}

Price atau harga di dalam marketing politik mencakup beberapa hal, mulai dari ekonomis, citra psikologis hingga citra nasional (Niffenegger, 1989). Harga ekonomi adalah banyaknya dana kampanye yang dikeluarkan selama periode kampanye, citra psikologis mengacu pada persepsi psikologis yang dialami pemilih, seolah-olah pemilih merasa nyaman dengan pasangan calon tersebut. Serta harga citra nasional yaitu apakah pemilih merasa pasangan calon dapat memberikan citra positif dan menjadi kebanggaan atau tidak.

\section{Place}

Place atau tempat terkait erat dengan bagaimana pasangan calon dapat memaksimalkan semua pemilih secara efektif. Kampanye politik pasangan calon harus mampu menjangkau semua lapisan masyarakat. Pasangan calon harus dapat mengelompokan, memetakan, serta menganalisa struktur dan karakteristik masyarakat. Identifikasi dilakukan dengan mengamati konsentrasi penduduk di suatu wilayah, penyebarannya dan kondisi fisik geografisnya. Pemetaan juga dapat dilakukan melalui demografi, di mana pemilih dikelompokkan berdasarkan tingkat pendidikan, pekerjaan, usia, kelas sosial, pemahaman tentang keyakinan politik, agama dan etnis. Pemetaan juga perlu didasarkan pada keberpihakan pemilih, seperti jumlah pendukung partai politik, berapa banyak pendukung kandidat lain, seberapa pemilih yang mengambang, dan juga berapa persentase golput.

\section{Marketing Politik 3p Menurut Adman Nursal}

Marketing politik menurut teori Adman Nursal (2004), yaitu push marketing, pull marketing, pass marketing.

1. Push marketing

Ini merupakan kegiatan menyampaikan produk politik secara langsung kepada pemilih. Yang dimaksud produk politik yaitu kandidat itu sendiri. Strategi ini dapat dilakukan melalui kegiatan kampanye berupa pertemuan akbar, pertemuan keagamaan, bakti sosial.

\section{Pull marketing}

Penyampaian produk politik dengan menggunakan media massa. Media massa memainkan peran yang sangat penting dalam kegiatan marketing politik, mengenalkan dan mensosialisasikan kandidat secara lebih luas. Selain itu, melalui media massa, kandidat dapat menyebarkan visi, misi dan program mereka kepada calon pemilih. Strategi pull marketing dilakukan melalui kampanye politik menggunakan media cetak (surat kabar) dan media elektronik (televisi dan radio).

\section{Pass marketing}

Penyampaian produk politik (calon atau partai) melalui pihak ketiga yang dinilai mampu mempengaruhi pemilih, diantaranya, tokoh masyarakat, tokoh pemuda atau tokoh-tokoh lain yang berpengaruh. Pihak-pihak yang memiliki pengaruh pada masyarakat memiliki nilai strategis bagi kandidat karena dengan adanya pengaruh, tokoh tersebut dapat menyampaikan pesan politik kandidat kepada masyarakat atau pemilih. Strategi pemasaran dilakukan melalui 
pembentukan hubungan politik dengan tokoh agama, tokoh masyarakat dan tokoh pemuda. Dalam kasus ini, seorang kandidat dapat saja melakukan penandatangan kontrak politik sebagai ikatan yang kuat dengan tokoh tersebut, sehingga ketika seorang kandidat terpilih, masyarakat dapat menuntut komitmen politik yang tercantum dalam kontrak dan berkontribusi pada kepentingan masyarakat setempat.

\section{Perbandingan Teori}

Teori Marketing politik menurut Niffenneger dan Adman Nursal memiliki persamaan pada tema pemasaran politik yang hendak dilakukan oleh kandidat atau tim kampanye dalam arena pemilihan umum. Perbedaan yang kentara antara kedua teori adalah teori Niffenneger lebih rinci dalam membahas strategi pemasaran politik yang mencakup produk yaitu kontestan itu sendiri, kampanye, biaya yang harus dikeluarkan serta lokasi dimana kandidat akan menargetkan suara pemilih.

Sedangkan Teori Adman nursal lebih kepada teknik dari kampanye kandidat dalam melakukan pemasaran politik dilapnagan. Yaitu secara langsung, menggunakan media massa dan menggunakan pihak ketiga (tokoh masyarakat, elite lokal) yang dinilai memiliki pengaruh.

Dari hasil studi literatur yang penulis lakukan, mendapatkan temuan bahwa pada dasarnya kedua teori dapat saling melengkapi di lapangan. Teori Niffenneger digunakan kandidat untuk memahami secara jelas strategi dan langkah yang digunakan dalam rangka meraup simpati pemilih pada pemilu. Teori ini menjelaskan secara rinci dan komprehensif menyangkut sejumlah kesiapan seorang kandidat untuk bertarung dalam pentas demokrasi.

Disisi lain teori Adman Nursal adalah teknik kampanye yang dilakukan seorang kandidat ketika pemilu. Tidak dapat dipungkiri bahwa kandidat tetap akan menggunakan teori Adman Nursal dalam rangka kampanye dilapangan. Yaitu melalui teknik kampanye diri secara langsung, menggunakan media dan pihak ketiga yaitu elite lokal.

\section{SIMPULAN}

Dari pembahasan di atas maka dapat disimpulkan bahwa teori bauran marketing promotion, price dan place dipandang lebih kompleks. Teori ini menurut pendapat penulis cakupannya lebih luas, sehingga riset yang dilakukan lebih menyeluruh dan hasil yang diperoleh akan lebih komprehensif. Jika di pahami lebih mendalam maka teori 3P yang dikemukakan Nursal merupakan bagian dari teori 4P yaitu promotion.

Pada dasarnya kedua teori dapat saling melengkapi di lapangan. Teori Niffenneger untuk memahami peta pemasaran politik. Sedangkan teori adman nursal lebih kepada teknik promosi atau kampanye kandidat di level akar rumput (masyarakat).

\section{DAFTAR PUSTAKA}

Agama, Y, (2015), "Strategi PDI Perjuangan dalam Memenangkan Pasangan Jokowi-Jusuf Kalla pada Pemilihan Presiden dan Wakil Presiden 2014". Jurnal Politico. Vol 2, No 6, 18 Desember 2017.

Bungin, B. (2012). Analisis Data Penelitian Kualitatif, Cetakan ke-8. Jakarta: Rajagrafindo Persada.

Butler, P., \& Collins, N. (2001). Payment on delivery: recognizing constituency service as political marketing, European Journal of Marketing, (35), 9-10, hlm. 1026-1037.

Creswell, J.W. (1998). Qualitatif Inquiry and Research Design; hoosing Among Five Traditions, Sage Publication, California.

Danial \& Wasriah. (2009). Metode Penulisan Karya Ilmiah. Bandung: Laboratorium Pendidikan Kewarganegaraan UPI

Firmanzah. (2012). Marketing Politik: Antara Pemahaman dan Realitas, Jakarta: Yayasan Pustaka Obor Indonesia.

Insani, M.A, (2013), Strategi Kemenangan Pasangan Tatto Suwarto Pamuji - Akhmad Edy Susanto dalam Pilkada Kabupaten Cilacap Tahun 2012. Journal of Politic and 
JPPUMA: Jurnal Ilmu Pemerintahan dan Sosial Politik UMA (Journal of Governance and Political Social UMA),

6 (2) (2018): 106-111

Government Studies. Volume 2, Nomor 1, 19 Desember 2017.

Kotler, P., \& Levy, S.J. (1969). Broadening the Concept of Marketing, Journal of Marketing, (33), 1, hlm. 10-15.

Niffenegger, P.B. (1989), Strategies for Success from the Politic Marketers. Journal of Consumer Marketing, Vol. 30, No. 10/11, pp. $45-51$

Nimmo, D. (2010). Komunikasi Politik Khalayak dan Efek. Bandung: PT Remaja Rosdakarya.

Nursal, A. (2004). Political Marketing Strategi Memenangkan Pemilu Sebuah Pendekatan Baru Kampanye Pemilihan DPR, DPD, Presiden, Jakarta: Gramedia.
O'Class, A. (1996). Political Marketing and The Marketing Concept. European Journal of Marketing, Vol 30.

O'Shaughnessy, N. (2001). The Marketing of Political Marketing. European Journal of Marketing, (35), 9-10, hlm. 1047-1067.

Peter, J.P. \& Olson, J.C. (1999). Perilaku konsumen dan strategi marketing edisi keempat (terjemahaan). Jakarta: Erlangga.

Sembang, R. (2013), Marketing Politik Pasangan Christiany Eugenia Paruntu dan Sonny Tandayu pada Pilkada Kabupaten Minahasa Selatan Tahun 2010. Jurnal Politico. Vol 1, No 3, 17 Desember 2017. 